\title{
Polynesian Finger Prints: Ellice Islanders
}

\author{
A. M. O. Veale and W. E. Adams
}

Although our knowledge of Polynesian dermatoglyphics is still relatively scanty, a clearer picture is gradually emerging, as records of different Polynesian groups accumlate. Commencing with the Maoris of New Zealand* (PoLL, 1938b; see ADAMS, 1963), studies have since been made of more Maoris (VEALE and Adams, 1965), Samoans (Suzuki, 1961; Shima, 1963), Maupiti (Society) islanders (Shima, 1963) and Tongans (Shima, 1967). From these studies, it is apparent that among the Polynesians the frequency of whorls generally greatly exceeds that of loops, and that the frequency of arches is extremely low (they may be entirely absent, as in the sample of Maupiti islanders). Indeed, apart from a very few groups in which the numbers of subjects examined have been very small (Mangyans of the Philippines and Oroks of Sakhalin, particularly; but also a small group of Brazilian Indians studied by LESTRANGE, 1954, having a whorl percentage of $73.1 \%$ ), the Polynerians have the highest whorl frequencies of any race in the world. The present investigation extends the study of the Polynesians to the natives of the Ellice Islands.

\section{MATERIAL AND METHODS}

With the kind permission of Mr.Tupua Leupena, Acting District Commissioner of the Ellice Islands District, Gilbert and Ellice Islands Colony, and the generous assistance of Mrs.Ailsa ClAGUE who took the prints, and to whom we wish here to express our deep gratitude, we have obtained palm and finger prints of 114 individuals ( 47 males and 67 females). Rolled impressions of the finger prints were made on "Kleenprint" paper supplied by Reed Laboratories, London. Two of the male prints were unfortunately so smudged as to be indistinct, reducing the number of suitable male prints to 45 . In seven instances ( 3 male and 4 female), one finger print was either missing, or unreadable due to a skin defect.

Thirteen different families were involved in the sample, and they included some persons (9) with European, Chinese, Samoan, Jamaican or Indian blood. One adopted female was described as a Samoan (curiously, she was the only female in whom all ten prints were loops), and one male was described as European-Samoan.

*HISAPHUSA is quoted by PIEBENGA (1938) as having studided 204 Tongans. No date or other reference to this source is given by PIEBENGA, and we have not been able to trace it. 


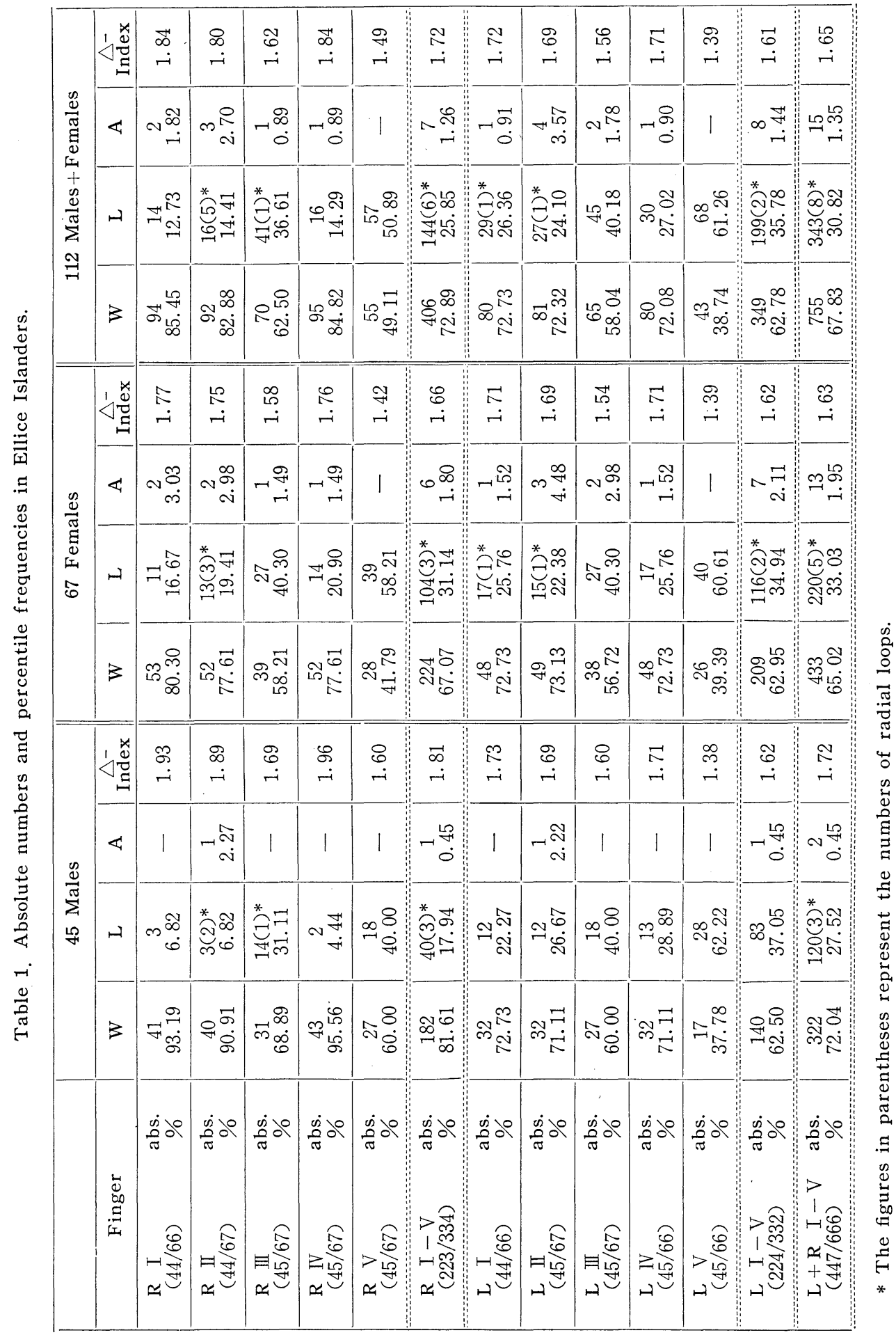




\section{RESULTS}

The absolute numbers and percentile frequencies of the patterns for each finger are recorded for males and females, separately and combined, in Table 1, which also gives the indices of pattern-intensity $(\triangle$-index) for each finger according to the method of Poll (KIRChMAIR and Poll, 1936). In Table 2 are shown the pattern combinations for separate hands, as well as the number of individuals in whom symmetrical patterns appear in the two hands. Table 3 gives the frequency of symmetry of identical pattern types in homologous pairs of fingers.

The deltadiagram which displays graphically the variations, finger by finger, in the $\triangle$-indices (see ADAMS, 1963b) appears in Figure 1; and the dactylodiagram (POLL, 1938a) in which the percentages of whorls are plotted, finger by finger, against the percentages of arches, as Figure 3.

The bimanuar combinations are shown graphically, according to POLL's method (1928, 1931), in Figure 4.

\section{DISCUSSION}

The Ellice Islanders, because of the very high frequency of whorls and the paucity of arches in their fingers, conform closely to what must now be accepted as a distinguishing dermatoglyphic characteristic of the Polynesian peoples-a predominance of whorls, and a great diminution of arches.

As with other Polynesians, the index of pattern intensity is very high (1.65), being exceeded-apart from other Polynesians (Maupiti islanders 1.81, and Maoris 1.67)-only by the Mangyans of Mindoro (1.90, Weninger, 1953), the Aeta of Camarines (1.67, Weninger, 1953) and the Oroks of Sakhalin (1.80, see Veale and Adams, 1965). (East Arnhem Land Australian aborigines, a small group of East Greenland Eskimos, and 27 Parana Indians of Brazil, also show higher indices, but not the Australian aborigines, Eskimos or American Indians as a whole.)

The deltadiagram, as in the case of other Polynesian groups, cannot be completed in the customary way (Figure 1). The principal reason for this is the invariably high index of pattern intensity (and whorl frequency) in the index fingers, which is a striking feature of all Polynesian groups so far studied(Figure 1). Certain other high-whorl races also show this characteristic-Australian aborigines, Papuans, Aeta of the Philippines-but none of these has a deltadiagram resembling that of the Polynesians; for, in the case of the Australians and $\mathrm{Pa}$ puans, the thumb $\triangle$-indices are invariably very low (in contrast to the Polynesians where they tend to remain high), while in the Aeta the little finger $\triangle$ - 


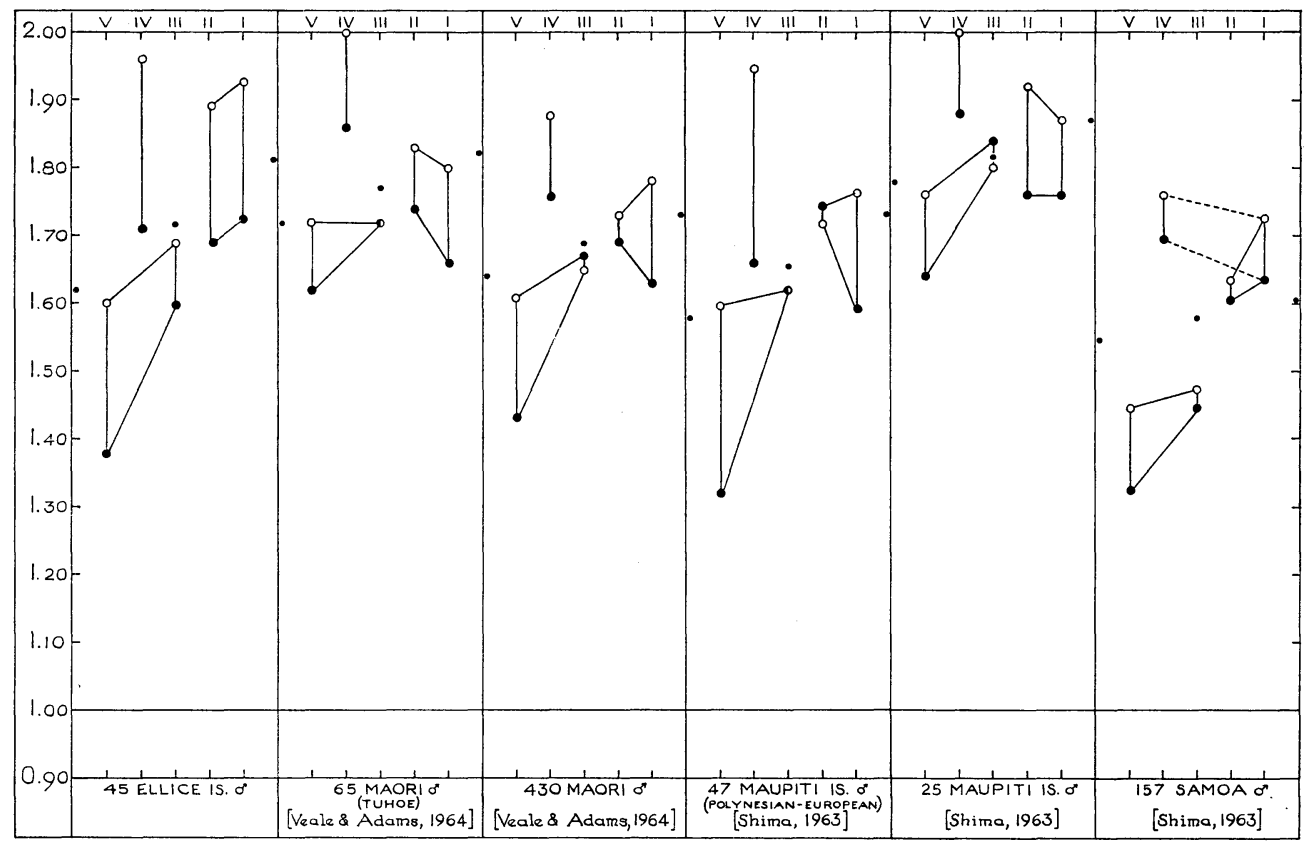

Fig. 1. Deltadiagrams of Polynesians (males), Ellice İslanders at the extreme left. In all cases, except the Samoans, the usual quadrilateral linking the thumb and ring fingers cannot be formed, owing to the high frequency of index finger $\triangle$-indices, a characteristic of all Polynesian groups so far studied. Thus, if a quadrilateral is to be drawn, it must link the thumb and index finger, as shown.

indices are unusually high, resulting in both cases in a distinctly different form of deltadiagram. The Mangyans (Philippines) and the Oroks (Sakhalin) are also groups with high whorl and low arch frequencies; in both cases, however, the indices of pattern intensity on the middle finger are unusually high, and so far above those of the little finger that a unique form of deltadiagram emerges (Figure 2). In the Polynesians, although the middle finger $\triangle$-indices are somewhat variable in the different groups which have been studied, they tend (as in Australian aborigines) to be rather higher than usual.

The dactylodiagram of the Ellice islanders, in which the pair-group rule (PoLL, 1938; Cummins and Midlo, 1943) is valid for both sexes separately and combined (Figure 3), differs from the customary dactylodiagram in that the indexfinger pair-as might be expected from its unusually high whorl percentageintervenes between the right and left thumb-annular groups (it is this, of course, which prevents the completion of the conventional deltadiagram). However, the dactylodiagram, unlike the deltadiagram, does not have a consistent form in the different Polynesian races-principally due to the variable position of the middle- 


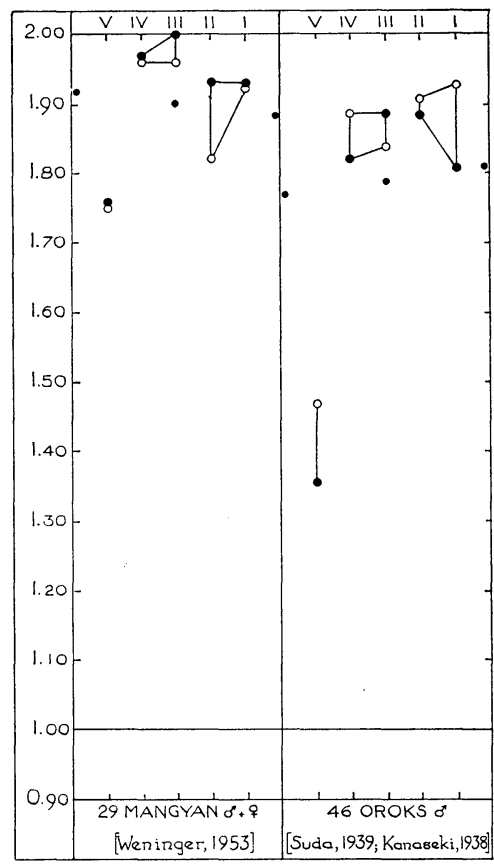

Fig. 2. Deltadiagrams of the Mangyans (Philippines) and the Oroks(Sakhalin). Note the extremely high middle finger $\triangle$ indices which pair most appropriately, not with the little finger, as usual, but with the ring finger. As in the Polynesians, the index finger indices are also unusually high. finger pair, and also to the fact that the whorl frequencies are in some cases relatively low in the left thumb. To what extent these variations in the different groups of Polynesians may prove to be of value in tracing affinities between them, must await much more extensive data than we have at present.

As for the combinations of the finger print patterns in both hands, the bimanuar (BLüMEL and POLL, 1928 ; Poll, 1928, 1931) shows distinctly the Polynesian characteristic, viz., the "wall" formed by the combinations in the $\mathrm{O}$ arch column declines markedly from the all-whorl square to the all-loop square (Figure 4). Of all other races in the wolrd, only the Mangyans and the Oroks show the same feature.

The proportion of arches (1.35\%), however, is rather higher than that of other Polynesian groups, except the Samoans (1.1\%) studied by SHima, (1963), and the Tongans (3.1\%) sampled by HisApHUSA (but in those sampled by SHI-

MA, 1967, the percentage is only $0.5 \%)$. Of the arches, $46.7 \%$ were on the index-fingers (right $42.9 \%$; left $50 \%$ ). As in most races-but unlike the Maoris - there is a slight excess of arches in the left hand, and the females conform to the general rule in having a considerably higher incidence of arches than the males.

Because loops as a whole are greatly reduced, radial loops-which, as usual,

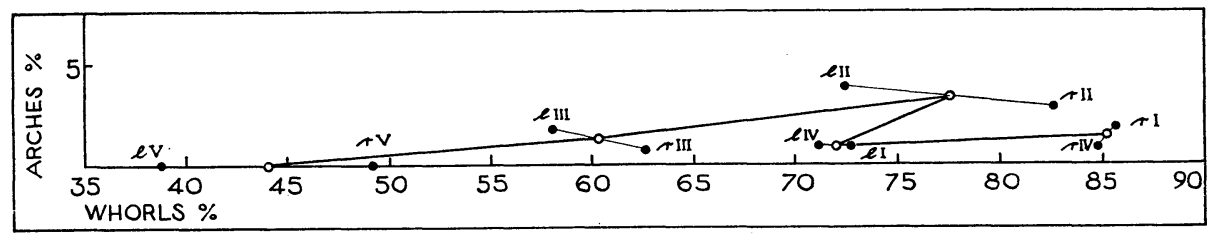

112 ELLICE IS. $\sigma^{*}+q$

Fig. 3. Dactylodiagram of Ellice Islanders. Pair-group rule valid, but index finger pair unusually placed, owing to very high whorl frequencies. 


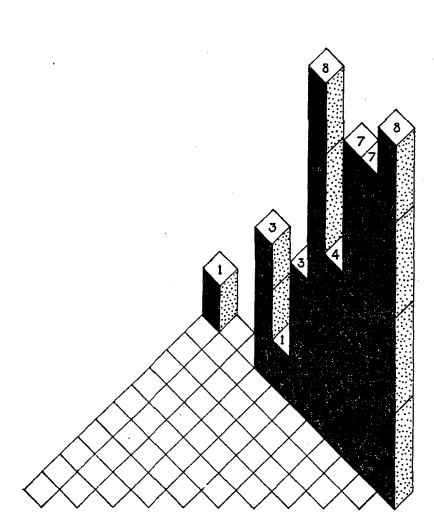

42 Ellice Is. 6

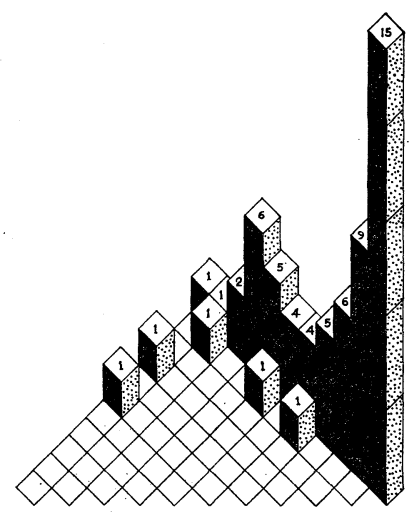

63 Ellice ls. 우

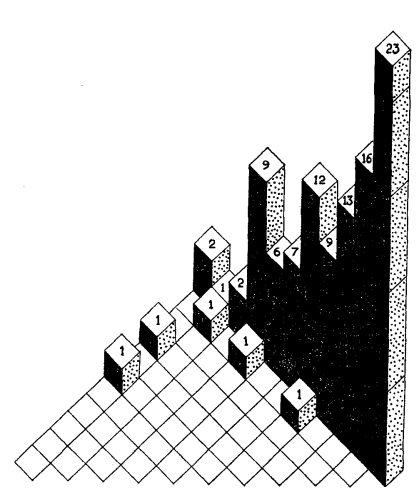

105 Ellice Is. $\sigma^{\prime \prime}+$ 우

Fig. 4. Bimanuars of Ellice Islanders. The bimanuar (PoLL, 1928, 1931) is turned through $90^{\circ}$ so that the all-loop square (at the right angle) is above, and the O-loop column forms the hypotenuse. The heights of the columns are proportional to the percentile frequencies of the different combinations (the transverse lines on each column each represents $5 \%$ ). The absolute numbers of each combination are shown at the tops of the columns.

preponderate on the index-fingers (75\%)-are very uncommon (0.72\%). As a percentage of all loops, however, they are-like the Maoris (0.87\%), Tongans (2.3\%, Shima, 1967), Samoans (2.17\%) and Maupiti islanders (2.58\%)-disproportionately reduced in Ellice islanders since they form here only $2.32 \%$ of all loops compared with the Europeans (in whom they formed $8 \%$ or more), and

Table 2. Finger print combinations in separate hands, and symmetrical combinations.

\begin{tabular}{|c|c|c|c|c|c|c|c|c|c|c|c|}
\hline \multicolumn{5}{|c|}{ Combinations } & \multicolumn{2}{|c|}{$\delta$} & \multicolumn{2}{|c|}{ 우 } & \multicolumn{2}{|c|}{$\begin{array}{c}\text { Both } \\
\text { Hands }\end{array}$} & \multirow{2}{*}{$\begin{array}{l}\text { Totals } \\
\text { (separate } \\
\text { hands only) }\end{array}$} \\
\hline $\mathrm{I}$ & III & III & IV & $\mathrm{V}$ & $\mathrm{R}$ & $\mathrm{L}$ & $\mathrm{R}$ & $\mathrm{L}$ & $\delta$ & 우 & \\
\hline W & $\mathrm{W}$ & $\mathrm{W}$ & W & $\mathrm{W}$ & 19 & 10 & 24 & 16 & 8 & 15 & 69 \\
\hline W & W & W & W & $\mathrm{U}$ & 9 & 7 & 10 & 14 & 2 & 6 & 40 \\
\hline W & W & $\mathrm{U}$ & W & W & 5 & 2 & 2 & 2 & $\overline{1}$ & - & 11 \\
\hline $\mathrm{U}$ & W & W & W & W & - & 1 & - & 3 & - & - & 4 \\
\hline- & W & W & W & W & 1 & - & - & - & - & - & 1 \\
\hline W & - & W & W & W & 1 & - & - & - & - & - & 1 \\
\hline $\mathrm{W}$ & $\mathrm{W}$ & $\mathrm{W}$ & $\mathrm{W}$ & - & - & 一 & - & 1 & - & - & 1 \\
\hline W & W & $\mathrm{U}$ & W & $\mathrm{U}$ & 4 & 2 & 5 & 3 & - & 1 & 14 \\
\hline $\mathrm{U}$ & W & W & W & $\mathrm{U}$ & - & 2 & 1 & 1 & - & - & 4 \\
\hline W & $\mathrm{U}$ & W & W & $\mathrm{U}$ & - & $\overline{2}$ & - & 1 & - & - & 3 \\
\hline W & W & W & $\mathrm{U}$ & $\mathrm{U}$ & - & 1 & 1 & 1 & - & - & 3 \\
\hline $\mathrm{U}$ & $\mathrm{U}$ & W & W & $\mathrm{W}$ & - & 1 & 1 & - & - & - & 2 \\
\hline W & $\mathrm{R}$ & W & W & $\mathrm{U}$ & 1 & - & 1 & - & - & - & 2 \\
\hline W & $\mathrm{U}$ & $\mathrm{U}$ & W & W & - & - & 二 & 2 & - & - & $\overline{2}$ \\
\hline W & W & $\mathrm{U}$ & $\mathrm{U}$ & W & - & - & - & 1 & - & - & 1 \\
\hline - & $\mathrm{W}$ & $\mathrm{W}$ & $\mathrm{U}$ & W & - & - & - & 1 & - & - & 1 \\
\hline
\end{tabular}


Table 2. (contd.)

\begin{tabular}{|c|c|c|c|c|c|c|c|c|c|c|c|}
\hline W & W & $\mathrm{U}$ & $\mathrm{U}$ & $\mathrm{U}$ & - & 4 & 3 & 2 & - & - & 9 \\
\hline $\mathrm{W}$ & $\mathrm{U}$ & $\mathrm{U}$ & W & $\mathrm{U}$ & - & I & 3 & 1 & - & 1 & 4 \\
\hline $\mathrm{U}$ & W & $\mathrm{U}$ & W & $\mathrm{U}$ & - & 1 & 2 & 1 & - & 2 & 4 \\
\hline $\mathrm{U}$ & $\mathrm{U}$ & W & W & $\mathrm{U}$ & - & 2 & $\overline{1}$ & - & - & - & 3 \\
\hline W & $\mathrm{U}$ & $\mathrm{U}$ & $\tilde{U}$ & W & - & 1 & - & - & - & - & 1 \\
\hline $\mathrm{U}$ & W & W & $\mathrm{U}$ & $\mathrm{U}$ & - & 1 & - & - & - & - & 1 \\
\hline W & W & $\mathrm{R}$ & $\mathrm{U}$ & $\mathrm{U}$ & 1 & - & - & - & - & - & 1 \\
\hline W & $\mathrm{R}$ & $\mathrm{U}$ & W & $\mathrm{U}$ & 1 & - & - & - & - & - & 1 \\
\hline $\mathrm{U}$ & $\mathrm{W}$ & $\mathrm{U}$ & $\dot{U}$ & W & - & - & - & 1 & - & - & 1 \\
\hline $\mathrm{W}$ & W & $\mathrm{A}$ & $\mathrm{U}$ & $-\mathrm{U}$ & - & - & 1 & L & - & - & 1 \\
\hline $\mathrm{U}$ & $\mathrm{U}$ & $\mathrm{U}$ & W & W & - & - & 1 & - & - & - & 1 \\
\hline W & W & $\mathrm{U}$ & - & $\mathrm{U}$ & - & - & - & 1 & - & - & $\overline{1}$ \\
\hline W & $\mathrm{U}$ & $\mathrm{U}$ & $\mathrm{U}$ & $\mathrm{U}$ & - & 2 & 2 & 3 & - & 1 & 7 \\
\hline $\mathrm{U}$ & W & $\mathrm{U}$ & $\mathrm{U}$ & $\mathrm{U}$ & - & - & 3 & 1 & - & $\perp$ & 4 \\
\hline $\mathrm{U}$ & $\mathrm{U}$ & $\mathrm{U}$ & W & $\mathrm{U}$ & - & - & - & 2 & - & - & 2 \\
\hline $\mathrm{U}$ & $\mathrm{U}$ & $\mathrm{U}$ & $\mathrm{U}$ & W & - & 1 & - & - & - & - & 1 \\
\hline $\mathrm{U}$ & A & $\mathrm{U}$ & W & $\mathrm{U}$ & 1 & L & - & - & - & - & 1 \\
\hline $\mathrm{U}$ & W & $\mathrm{R}$ & $\mathrm{U}$ & $\mathrm{U}$ & L & 1 & - & - & - & - & 1 \\
\hline W & $\mathrm{R}$ & $\mathrm{U}$ & $\mathrm{U}$ & $\mathrm{U}$ & - & I & 1 & - & - & - & 1 \\
\hline $\mathrm{U}$ & $\mathrm{R}$ & $\mathrm{U}$ & W & $\mathrm{U}$ & - & - & 1 & - & - & - & 1 \\
\hline $\mathrm{U}$ & $\mathrm{W}$ & $\mathrm{U}$ & $\mathrm{A}$ & - & - & 1 & - & - & - & - & 1 \\
\hline $\mathrm{U}$ & $\mathrm{U}$ & $\mathrm{U}$ & $\mathrm{U}$ & $\mathrm{U}$ & 1. & 2 & 1 & 3 & 1 & 1 & 7 \\
\hline $\mathrm{U}$ & A & $\mathrm{U}$ & $\mathrm{U}$ & $\mathrm{U}$ & - & - & $\stackrel{1}{-}$ & 2 & 1 & 1 & 2 \\
\hline $\mathrm{U}$ & A & A & $\mathrm{U}$ & $\mathrm{U}$ & - & - & - & 1 & - & - & 1 \\
\hline $\mathrm{R}$ & $\mathrm{U}$ & $\mathrm{U}$ & $\mathrm{U}$ & $\mathrm{U}$ & - & - & - & 1 & - & - & 1 \\
\hline A & A & $\mathrm{U}$ & $\mathrm{U}$ & $\mathrm{U}$ & - & - & 1 & 亡 & - & - & 1 \\
\hline A & $\mathrm{A}$ & $\mathrm{U}$ & A & $\mathrm{U}$ & - & - & 1 & - & - & - & 1 \\
\hline $\mathrm{U}$ & $\mathrm{R}$ & $\mathrm{U}$ & A & U & - & - & $\stackrel{\perp}{-}$ & 1 & - & - & 1 \\
\hline $\mathrm{A}$ & $\mathrm{U}$ & A & U & $\mathrm{U}$ & - & - & - & 1 & - & - & 1 \\
\hline- & $\mathrm{U}$ & $\overline{\mathrm{U}}$ & $\mathrm{U}$ & $\mathrm{U}$ & - & - & 1 & - & - & - & 1 \\
\hline \multicolumn{5}{|c|}{ TOTALS } & 45 & 45 & 67 & 67 & 12 & 25 & 22 \\
\hline
\end{tabular}

Japanese and Chinese (about 6\%-7\%).

Again, as in the Maoris, the most frequent combination in single hands is WWWWW (30.85\% as compared with $31 \%$ in all Maoris). The next most numerous combination is, again like the Maoris, WWWWU (17.86\%, Maoris $13.1 \%)$. All-loop and other no-whorl combinations are almost as rare as in the Maoris (7.14\% as against 6.6\%), again especially in right hands (4.47\%; Maoris $3.8 \%$ ). Twelve males (26.7\%) and 25 females (37.3\%) showed absolute symmetry (KIRCHMAIR, 1935). i. e., identical patterns in corresponding fingers of the two hands (cf., Maoris, 38\% and 35\%).

Table 3. Symmetry of finger print patterns in homologous pairs of fingers.

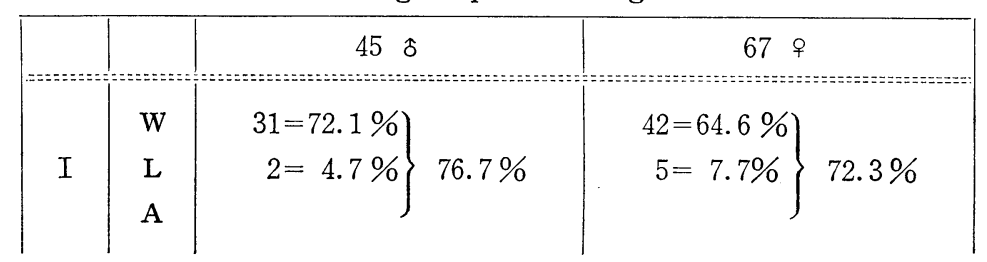


Table 3. (contd.)

\begin{tabular}{|c|c|c|c|c|c|}
\hline II & $\begin{array}{l}\text { W } \\
\text { L } \\
\text { A }\end{array}$ & $\left.\begin{array}{rl}30 & =68.2 \% \\
2 & =4.5 \% \\
1 & =2.3 \%\end{array}\right\}$ & $75.0 \%$ & $\left.\begin{array}{rl}45 & =67.2 \% \\
8 & =11.9 \% \\
1 & =1.5 \%\end{array}\right\}$ & $80.6 \%$ \\
\hline III & $\begin{array}{l}\text { W } \\
\text { L } \\
\text { A }\end{array}$ & $\left.\begin{array}{rl}22 & =48.9 \% \\
9 & =20.0 \%\end{array}\right\}$ & $68.9 \%$ & $\left.\begin{array}{l}33=49.3 \% \\
21=31.3 \%\end{array}\right\}$ & $80.6 \%$ \\
\hline IV & $\begin{array}{l}\text { W } \\
\text { L } \\
\text { A }\end{array}$ & $\left.\begin{array}{r}32=71.1 \% \\
2=4.4 \%\end{array}\right\}$ & $75.6 \%$ & $\left.\begin{array}{r}43=65.2 \% \\
9=13.6 \%\end{array}\right\}$ & $78.8 \%$ \\
\hline V & $\begin{array}{l}\text { W } \\
\text { L } \\
\text { A }\end{array}$ & $\left.\begin{array}{l}16=35.6 \% \\
17=37.8 \%\end{array}\right\}$ & $73.3 \%$ & $\left.\begin{array}{l}23=34.8 \% \\
36=54.5 \%\end{array}\right\}$ & $89.4 \%$ \\
\hline \multicolumn{3}{|c|}{ AVERAGE } & $73.9 \%$ & & $80.3 \%$ \\
\hline
\end{tabular}

The frequencies of identical pattern types In homologous pairs of fingers from the right and left hands (Table 3) are, as in the Maoris, significantly greater than could be expected by chance. In both cases, this excess symmetry is much the same as in other racial groups which have been studied (see DANKMEIJER and RENES, 1938).

\section{SUMMARY}

The finger prints of the Ellice islanders, like those of other Polynesians, show very high whorl percentages, and a corresponding reduction in percentages of loops, the percentage of arches being also very low.

Males (45): whorls $=72.04 \%$; loops $=27.52 \%$; arches $=0.45 \%$.

Females (67): whorls $=64.87 \%$; loops $=33.18 \%$; arches $=1.95 \%$.

Males and females (112): whorls $=67.83 \%$; loops $=30.82 \%$; arches $=1.35 \%$.

These percentages are very similar to those of Maoris of close to pure blood (Samples A+B, Adams and Veale, 1965 ; whorls ; males, 73. 15\%, females, 68.93\%); they also approximate to those of Society Island Polynesian-European hybrids (whorls: males, $74.7 \%$; females, 69.9\%).

The deltadiagram also conforms closely to that of other Polynesian races so far studied; it differs from that of the Mangyan (Philippines) and Oroks (Sakhalin)-other high-whorl circum-Pacific groups-in whom the middle-fingers show exceptionally high indices of pattern intensity. 


\section{ACKNOWLEDGMENTS}

In addition to those already mentioned, we are grateful to Professor G. Shima, of Osaka City University Medical School for his continued generous assistance with references and data; and to Miss M. Ogilvie, of the Anatomy Department, who prepared the figures.

\section{LITERATURE CITED}

AdAMS, W. E., 1963a: Fingerprints of the New Zealand Maori. J. Anat., Lond., 97: 483-484.

- 1963b: The deltadiagram : a new graphical method for the study of racial dermatoglyphics. J. Anthrop. Soc. Nippon, 71: 133-142.

BLÜMEL, P. and H. POLL, 1928: Fingerlinienmuster und geistige Norm. Med. Klinik, 24 : 1424-1430.

Cummins, H. and C. Midlo, 1943: Finger Prints, Palms and Soles. Philadelphia: Blakiston. $309 \mathrm{pp}$.

DANKMEIJER, J. and R. C. RENES, 1938: General rules in the symmetrical occurrence of papillary patterns. Am. J. phys. Anthrop., 24: 67-79.

HisAPHUSA (cited by PIEBENGA, 1938)

KANASEKI, T., 1938: On the finger and palm patterns of the natives of Sakhalin (Oroks, Giliaks and Sanda). J. Anthrop. Soc. Tokyo, 48: 30-37. (In Japanese)

KIRChMAIR, H., 1935: Über relative und absolute Symmetrie der Papillarmuster bei gesunden und kranken Populationen. Z. Morph. Anthrop., 33: 464-473.

KIRCHMAIR, H. and H. POll, 1936: Zur Charakteristik des Rassenunterschiedes des Dactylodiagramms. Biologia generalis, $12: 202-216$.

Lestrange, M. de, 1954: Dermatoglyphes digitaux et palmaires de 47 Indiens du Brèsil. Bull. Mem. Soc. Anthrop., Paris, 5: 85-86.

PiebengA, H. T., 1938: Systematische und erbbiologische Untersuchungen über das Hautleistensystem der Friesen, Flamen und Wallonen. Z. Morph. Anthrop.. 37: 140-165.

Poll, H., 1928: Seltene Menschen. Anat. Anz., Ergänzungsh., 66: 18-30.

—, 1931: Das Manuar oder die Verteilung der Fingerlinienmuster bei verschiedenen Rassen. Verhl. Ges. phys. Anthrop., 5: 49-59.

- 1938a: Two unlike expressions of symmetry of finger-tip patterns. Human Biol., 10: 77-92.

—, 1938b: Die Deltiegramm. (Unpublished manuscript in possession of W. E. A.)

ShimA, G., 1963: Über das Hautleistensystem der Finger- und Zehnenbeeren der Polynesier und der gemischten Polynesier. Osaka City Univ. med. J., 9: 53-66.

- 1967: Personal communication.

SuzUki, M., 1961: Anthropologic research of Polynesians. Proc. Jt. Meeting Anthrop. Soc. Nippon and Jap. Soc. Ethnol., 15: 137-140.

SudA, A., 1939: On the palm and sole pattern in the Oroks and Giliaks. J. Anthrop. Soc. Tokyo, 54: 9-35 (In Japanese, with English summary).

Veale, A. M. O. and W. E. Adams, 1965: Fingerprints of the New Zealand Maori. J. Anthrop. Soc. Nippon, 73: 33-49.

Weninger, M., 1953: Finger-und Handabdrücke von Eingeborenen der Philippinen und der Malayischen Halbinsel. Mitt. anthrop. Ges, Wien, 82: 92-120. 
Human Genetics Unit and Department of Anatomy, University of Otago, Dunedin, New Zealand

\author{
ポリネシア、エリス島人の指絞
}

A. M. O. Veale \& W. E. Adams

エリス島人の指紋々型頻度は, 他のポリネシア人同様に, 渦状紋は非常に多いが, 蹄状紋はかなり少な く, 弓状紋は非常に少ない。

$$
\text { エリス島人の指紋々型頻度（\%） }
$$

\begin{tabular}{|c|c|c|c|c|}
\hline 性別 & 調查人数 & 渦状紋 & 蹄状絞 & 弓状紋 \\
\hline & 45 & 72.04 & 27.52 & 0.45 \\
\hline of & 67 & 64.87 & 33.18 & 1.95 \\
\hline$+q$ & 112 & 67.83 & 30.82 & 1.35 \\
\hline
\end{tabular}

此等の頻度は準純血マオリの夫等 (A+B群, ADAMS \& VEALE, 1965：渦状紋； $8,73.15 \%$, \&, 68.93\%) 飞非常に類似している; 又, ソシエテ群島のポリネシア人一欧人混血群（渦状紋： $\$ ， 74.7 \%$; ค，69.9\%）にも近似している。

指紋三叉図屯亦, 既報告の諸ポリネシア人とよく一致している。然し, 中指々紋示数の非常に高いマン ギャン (フィリッピン) とオロッコ（樺太）一滑状紋の多い周迅太平洋群一とは相異している。 